\title{
CONVERSATIONAL IMPLICATURE IN Dialogue OF "LAYAR TERKEMBANG" NOVEL BY SUTAN TAKDIR Alisjahbana
}

\author{
TIKA MULIYANI ${ }^{1}$, MEISURI ${ }^{2}$, WIDYA ANDAYANI ${ }^{3}$ \\ ${ }^{123}$ UNIVERSITAS NEGERI MEDAN
}

\begin{abstract}
This research dealt with Conversational Implicature in Dialogue of LayarTerkembang Novel By SutanTakdirAlisjahbana based on Grice's Theory and it was aimed to finding out the types of conversational implicature, and to describe why the certain type of conversational implicature becomes dominant. This research was conducted by using descriptive qualitative method. The source of the data was taken from LayarTerkembang novelby SutanTakdirAlisjahbana, Then the dialogue of the novel as the data for the research. The findings showed that there were two types of conversational implicature in the procedures namely Generalized Conversational Implicature belong to 33 utterances and Particularized Conversational Implicature belong to 36 utterances. So, the most dominant types of conversational implicaturebetween the main characters in the novel was particularized conversational implicature because it more contained ambiguity, implicit meaning, conveyed an additional meaning, and their response did not relevant with every question and also it cannot easily to understand what he/she was talking about.
\end{abstract}

Keywords: Conversational Implicature; Generalized Conversational Implicature; Particularized Conversational Implicature 


\section{INTRODUCTION}

Humans use language as a tool to communicate with the surrounding environment. Communication is a way to send information and message to convey the ideas, feeling or everything in the mind within a particular context. We cannot communicate in any real sense without language. It can take in form of speech, letters email, text, or sign language. Most of people communicate in the form of conversation.

Conversation expresses the familiar kind of talk in which two or more participants freely alternate in speaking and generally occurs outside specific institutional settings. It is assumed that, there are at least two participants, the speaker and the addressee who carry out the conversation and they interchange the roles. When people make conversation they engage in a form of linguistic communication, but there is much more going on in a conversation than just the use of a linguistic code. The important thing to note is that language is not only in verbal form, but also movements, signals, or symbols. In other words, they often provide implicit meaning in their utterances. Therefore, it can make misunderstanding between speakers and hearers.

The implied meaning in a conversation is also called conversational implicature. Conversational implicature occur when the speaker's meaning is not part of the literal content of utterance, it might just add something else in the conversation (Davis 2007). While according to Grice (1975), Conversational Implicature is a species of speaker meanings and speaker meaning divides exhaustedly into what is said and what is implicated. It can also be called as the speaker's intention in doing communication. In this case, the speakers deliver an intention by saying something else. It is triggered by certain general features of discourse rather than by the conventional meaning of a specific word.

Grice state that there were two types of Conversational Implicature, namely generalized conversational implicature and particularized conversational implicature. Generalized conversational implicature isimplicature that arise without any particular contextor special scenario being necessary (Grundy, 2000). Therefore, generalized conversationalimplicature is inferable without reference to aspecial context. Whereas particularized conversational implicatureis an implicature where some assumed knowledge is required in very specific contexts during a conversation (Yule, 2006). A particularized conversational implicature occurs when a conversation takes place in very specific context and circumtance in which locally recognized inferences are assumed.

There have been several studies in conversational implicature, some of them are; Riza (2016)studied about the kinds of conversational implicature and its implied meaning on The Woodlanders novel. She found that particularized conversational implicature most dominant than generalized conversational implicature. Because there were many specific contexts than general that contain in the conversation of the novel. 
Indah (2017) studied about conversational implicature as found in Buyers and Sellers Interaction in the Traditional Market of LubukAlung. The result of the researchconcluded that thethe speakers (sellers and buyers) were more often flouted the maxim of manner. In contrast, maxim of quality wasthe fewestto be flouted by the speakers. In the conversation that have been recorded, female aremore often flouted the maxim than malebecause femalewere more likely to bargain inthetraditional marketthan male.

Aqromi (2016) investigated the implicatures used in the Debate between BarackObama and Jhon McCain by using Grice's theory. The findings of this research concluded that the use of both type generalized conversational implicature and particularized conversational implicature were balance in the debate.

This research conducted to analyze the types ofConversational Implicature in Dialogue of LayarTerkembang Novel by SutanTakdirAlisjahbanaand the most dominant types of conversational implicature in the dialogue among the characters in LayarTerkembang. The researcher limits the data only on dialogue that contains the conversational implicature of communication.

\section{RESEARCH METHODOLOGY}

This research was conducted by using a descriptive qualitative research. Hossein (2015) describe the goal of qualitative research is to describe a phenomenon and its characteristics. This research is more concerned with what rather than how or why something has happened. as involving an interpretive naturalistic approach to the world. This means the qualitative researchers study things in their natural settings, attempting to make sense of or interpret phenomena in terms of the meanings people bring tothem.

The source of the data was taken from LayarTerkembangnovelby SutanTakdirAlisjahbana, published by BalaiPustaka, first published in 1963, then the dialogue of the novel as the data for the research. The novel consists of 201 pages divided into three sections: the first sections (pages 3 to 100), the second sections (pages 103 to 107), and closing sections (pages 198 to 201). Then, it focused on the main characters namely Tuti, Maria and Yusuf. These three characters also raise more conversational implicature then other characters.STA is one of Indonesia's reformist figures with a liberal view. Because of its thoughts that tend to be pro-modernization as well as pro-Western, STA had time to argue with other Indonesian intellectuals. According to him, the Indonesian nation must catch up by looking for material, modernizing thinking, and learning Western sciences.Apart from being an expert on Indonesian grammar, STA is also a writer who has written many novels. Some examples of his famous novels areLayarTerkembang (1936), TakPutusDirundung Malang (1929), Dian TakKunjungPadam (1932), AnakPerawandiSarangPenyamun (1940), and GrottaAzzura (1970 \& 1971). 
The data of this research were collected by downloading the novel from internet, reading the novel for six times in one month, and finding out the utterances of the main characters namely Tuti, Maria, and Yusuf that containing conversational implicaturefrom the dialogue in the novel. After that the researcher was identified the types of conversational implicature in each utterance based on Grice's theory about conversational implicature, then counting the occurrences of each type of conversational implicature, next converting the occurrences into percentages and the last, the researcher wrote the description of the results of the analysis.

\section{FINDINGS and DISCUSSIONS}

\section{Findings}

There were two types of Conversational Implicature, namely Generalized Conversational Implicature and Particularized Conversational Implicature. It was found that there were 69 utterances of conversational implicature. The conversation were numbered from first section until closing section, but each of the sections in that section are not fully of conversation that containing conversational implicature. Here are the percentages of the types of conversational implicature.

Table 4.1 The Percentages of the Types of Conversational Implicature

\begin{tabular}{|c|lc|l|l|}
\hline No & $\begin{array}{l}\text { Types of Conversational } \\
\text { Implicature }\end{array}$ & $\begin{array}{l}\text { Frequency } \\
(\mathrm{F})\end{array}$ & $\begin{array}{l}\text { Percentages } \\
(\mathrm{X})\end{array}$ \\
\hline 1. & $\begin{array}{l}\text { Generalized } \\
\text { Implicature }\end{array}$ & Conversational & 33 & $47,8 \%$ \\
\hline 2. & $\begin{array}{l}\text { Particularized } \\
\text { Implicature }\end{array}$ & Conversational & 36 & $52,2 \%$ \\
\hline & Total (N) & 69 & 100 \\
\hline
\end{tabular}

The table shows that the two types of conversational implicature were in the dialogue of LayarTerkembang novel by SutanTakdirAlisjahbana. They were Generalized Conversational Implicature (33 utterances) and Particularized Conversational Implicature (36 utterances). The total number of conversational implicature was 69 utterances. The most dominant types of conversational implicature was Particularized Conversational Implicature (52,2\%).Discussions

\section{Discussions}

After analyzingthe data, there were some important points to be discussed. First, the researcher found the two types of conversational implicature in the dialogue of LayarTerkembangnovel such as generalized conversational implicature and particularized conversational implicature. There were 69 utterances, 33 utterances $(47,8 \%)$ belonged to generalized conversational implicature and 36 utterances $(52,2 \%)$ belonged to particularized conversational implicature. From the percentage, it can 
be seen that the most dominant of conversational implicature in the dialogue of LayarTerkembang is particularized conversational implicature.

Second, the researcher found that the reason why particularized conversational implicature became dominant types in Layar Terkembang novel because many utterances needed special knowledge to conceive the meaning of the utterances and this kind needed special knowledge of special context, which is only speaker and hearer understand about it.

From this discussion, we can see that this research different with 2 previous researches that also have same background, it is genre of the novel with the same dominant types namely particularized conversational implicature. First, a thesis which written by HanifahRiza focused on conversational implicature analysis on The Woodlanders novel. The difference among this research and the writer's research is HanifahRiza's thesis only focused on the kinds of conversational implicature but not on the main characters in The Woodlanders novel. Meanwhile this research focused on two types of conversational implicature on the main characters in the novel which contained many conversational implicatures.Second, it still in the same field, an analysis of conversational implicature in Taylor Morris's Hello,

Gorgeous! novel written by Putri (2018). These two researches doing research in the same background and another things make them different is used of the same theory but different in object. YuliaPutri was used Grice's theory that focused on conversational implicature that is connected with cooperative principle and maxim violations that exist in the dialogue of the novel. She also analyzed the types of conversation into three types namely generalized, scalar, and particularized implicature. While this research only focused on Grice's theory that analyzed conversational implicature into two types namely generalized and particularized implicature.

\section{CONCLUSIONS}

Based on the findings and discussions in previous section, the researcher concludes that there were two types of conversational implicature were occurred in the dialogue among the characters in LayarTerkembangnovel. They were Generalized Conversational Implicature (33 utterances) and Particularized Conversational Implicature (36 utterances). So, the most dominant types of conversational implicature in the novel was Particularized Conversational Implicature with 36 utterances $(52,2 \%)$. Those findings prove that conversational implicature was used as an effective tool of communication. One of them is communication between the main characters in LayarTerkembang novel. It can be said that the speaker had conveyed more than he/she said via conversational implicature, while hearer recognized the meaning via inference. For the case in which what speaker means or implied was different from what was said. The main character gave a particular implicit meaning that made utterances became ambiguity and their answered were mostly irrelevant with every question. There was needed special background knowledge to caught late the additional conveyed meaning and it cannot 
were able to understand what they were talking about. So, it was the reason particularized conversational implicature became dominant types in LayarTerkembang novel.

Based on the result of the study, the writer suggests forthe students who want to comprehend Pragmatics especially about conversational implicature so that they can get the meaning from conversation whether it's explicitly or implicitly. Besides, the writer hoped that the readers can get more understanding about the Conversational Implicature and the type of each conversational implicatures especially in the dialogue of the novel. Then, this research can be used as an additional reference for other researchers who are interested in studying further about conversational implicature and also they can analyze theconversational implicature, and knowing more the concepts of conversational implicature in dialogue.

\section{REFERENCES}

Aqromi. (2016). The Implicatures Used in the Debate Between Barrack Obama and Jhon McCain. Jurnal JITIKA. Vol 5 No (2), 36 - 5.

Davis, Wayne. (2007). Implicture: Intention, Convention, and the Principle of failure of Gricean theoriy. Brown University.

Grice, H. P. (1975). Logic and Conversation. New York: Oxford University Press.

Grundy, Peter. (2002). Doing Pragmatics. Arnold: London.

Hosseji. (2015). Qualitative and Descriptive Research: Data Type Versus Data Analysis. Language Teaching Research. Vol 19 (2), 129-132.

Indah. (2017).Conversational Implicature as found in Buyers and Sellers Interaction in the Traditional Market of Lubuk Alung. E-Journal of English Language and Literature. Vol 6 No 2, 1-8.

Putri, Y. (2018). An Analysis of Conversational Implicature in Taylor Morris's Hello, Gorgeous! Novel. Paradigma Lingua. Vol 6 No (2), 1 - 8.

Riza, H. (2016). Conversational Implicature Analysis on The Woodlanders Novel by Thomas Hardy. Thesis, English Education Department, Tarbiyah Faculty, State Islamic College of Ponorogo (STAIN) Ponorogo.

Yule. (2006). The Study of Language. New York: Cambridge University Press, 